\title{
Transcription Termination Factor 1
}

National Cancer Institute

\section{Source}

National Cancer Institute. Transcription Termination Factor 1. NCI Thesaurus. Code C107624.

Transcription termination factor $1(905 \mathrm{aa}, \sim 103 \mathrm{kDa}$ ) is encoded by the human TTF1 gene. This protein plays a role in transcription arrest. 